\title{
Penerapan Model Pembelajaran Savi Untuk Meningkatkan Hasil Belajar Forehand Drive Permainan Tenis Meja Mahasiswa Prodi PJKR Semester Ganjil FIK-Unimed
}

\author{
Zulpikar Ilham \\ Correspondence: Fakultas Ilmu Keolahragaan, Universitas Negeri \\ Medan, Medan, Indonesia \\ E-mail: zulpikar_ilham@yahoo.com
}

\begin{abstract}
This study is intended to examine the impact of the application of SAVI learning model to improve learning outcomes forehand table Tennis drive. With this research this study aims to determine the impact of the application of SAVI learning model to improve learning outcomes forehand table tennis drive. With this research is expected to improve learning results forehand table tennis drive on students majoring in PJKR FIK-Unimed. Application of this SAVI learning model will help lecturers to determine the appropriate learning stages of the difficulty level, so that the students can master the technique well and also encourage improving learning outcomes. This study uses action research methods developed by Kemis. The research activity plan is conducted with 2 cycles with each cycle consisting of 4 stages; (1) phase 1, do the planning. In this planning the researcher performs the initial test, identification of resource requirement, programming of learning program plan and determination of achievement indicator, (2) second stage, implementation. At this stage, a step-by-step learning process is based on the learning program plan, (3) third stage, observation. At this stage observation is attached to each exercise and perform tests and measurements, (4) fourth stage, do reflection. Reflection is done to find some obstacles and problems and then become the basis for determining activities in the second cycle. Output target in this research is minimal journal with ISSN.
\end{abstract}

\section{Key Words: Learning Results Forehand Drive Table}

\section{Pendahuluan}

Proses kegiatan belajar mengajar merupakan suatu aktivitas yang bertujuan mengarahkan peserta didik pada perubahan tingkah laku yang diinginkan. Pengertian ini kelihatan cukup simpel dan sederhana, akan tetapi pengertian ini ditelaah lebih mendasar, maka akan terlihat rumit dan begitu kompleksnya proses yang dituntut dalam mengelola pelajaran itu sendiri. Hal tersebut bisa dipahami karena mengarahkan peserta didik menuju perubahan merupakan suatu pekerjaan yang berat. Pekerjaan ini membutuhkan suatu perencanaan yang matang, berkesinambungan serta carapenerapan kepada peserta didik.

Pendidikan nasional berfungsi mengembangkan kemampuan dan berbentuk watak serta peradaban bangsa yang bermartabat dalam rangka mencerdaskan kehidupan bangsa, bertujuan untuk berkembangnya potensi peserta didik agar menjadi manusia yang beriman dan bertaqwa mulia, sehat, berilmu, cakap, kreatif, mandiri, dan menjadi warga Negara yang demokratis serta bertanggung jawab.

PJKR_

http://jurnal.unimed.ac.id/2012/index.php/jpehr/index 
Tujuan pendidikan nasional menjadi tujuan yang sangat ideal, seperti hal dalam meningkatkan keimanan dan ketaqwaan peserta didik, juga bertujuan untuk meningkatkan aspek psikomotor, kognitif dan afektif, serta pengembangan pengetahuan tentang kesehatan peserta didik. Sehingga di upayakan belajar untuk menghadapi perubahan dan permasalahan, proses penemuan, proses menjadi dan mengembangkan diri sendiri dalam keseluruhan dimensi kepribadian dan proses belajar sepanjang hayat.

Pembelajaran yang baik adalah pembelajaran yang mampu melibatkan keaktifan mahamahasiswa dalam proses pembelajaran. Mahamahasiswa diarahkan untuk menyelesaikan masalah pembelajaran sesuai dengan konsep yang dipelajari.pendekatan mengajar merupakan aspek penting dalam aspek belajar mengajar sebagai jalan untuk mencapai tujuan pengajaran.

Oleh karena itu diharapkan peran serta lembaga pendidikan dan kedosen an dalam menyiapkan tenaga-tenaga pendidikan terutama dosen yang akan memberikan pengajaran di dalam dan di luar kelas, dalam artian pengajar harus mampu memilih dan menerapkan metode pengajaran yang diprediksi akan lebih efektif untuk memudahkan mahamahasiswa dalam belajar dikelas dan diluar kelas maupun belajar mandiri.

Kemampuan memilih gaya mengajar yang relevan dan pemanfaatan teknologi di bidang pendidikan bukan sekedar suatu cara memvariasikan proses, melainkan suatu scenario besar untuk memfasilitasi agar mahamahasiswa banyak bergerak mencoba, inisiatif, kreatif dan banyak melakukan banyak hal secara fisik, mental, emosional dan sosial.

Marice Sianipar (2006) "Efektif tidaknya untuk mencapai tujuan pengajaran sangat tergantung kepada kemampuan dosen pemakaian gaya mengajar yang tepat (dikuasai dosen) akan meningkatkan pencapaian dan motivasi belajar pada murid, sedangkan penggunaan gaya mengajar yang tidak tepat (tidak dikuasai dosen) akan merupakan penghambat dalam proses belajar mengajar"(2006:47). Oleh karena itu semakin tepat metode yang digunakan dalam memberikan pelajaran, semakin efektif pula terhadap pencapaian tujuan pengajaran yang telah ditetapkan.

Banyak metode pengajaran yang dapat digunakan dalam pembelajaran mata kuliah tenis meja. Metode yang digunakan sebaiknya disesuaikan dengan materi pelajaran yang akan disampaikan. Beberapa metode mengajar dapat diterapkan selama pembelajaran berlangsung, tergantung dari keadaan kelas atau mahamahasiswa.

Melalui perkembangan teknologi pendidikan dan komunikasi yang pesat, maka media dalam pendidikan pun berkembang pesat pula, baik kuantitas maupun kualitasnya. Jenis media pembelajaran menjadi lebih banyak, diantaranya media visual, media kaset, media film, media video, media slide, media grafis, OHP, media mekanik dan sebagainya.

Pembelajaran SAVI adalah kolaborasi dari ilmu pengetahuan dan teknologi. SAVI singkatan dari Somatic, Auditori, Visual dan Intektual. Teori yang mendukung pembelajaran SAVI adalah Accelerated Learning, teori otak kanan/kiri; teori otak triune; pilihan modalitas (visual, auditorial dan kinestetik);

PJKR_

http://jurnal.unimed.ac.id/2012/index.php/jpehr/index 
teori kecerdasan ganda; pendidikan (holistic) menyeluruh; belajar berdasarkan pengelaman; belajar dengan symbol. Pembelajaran SAVI menganut aliran ilmu kognitif modern yang menyatakan belajar yang paling baik adalah melibatkan emosi, seluruh tubuh, semua indera, dan segenap kedalaman serta keluasan pribadi, menghormati gaya belajar individu lain dengan menyadari bahwa orang belajar dengan cara-cara yang berbeda. Mengkaitkan sesuatu dengan hakikat realitas yang nonlinear, nonmekanis, kreatif dan hidup.

Berdasarkan hasil observasi pra penlitian Tahun Ajaran 2017 , mahamahasiswa kelas masih mengalami kesulitan dalam melakukan teknik Forehand dalam pembelajaran Tenis Meja, khususnya teknik Forehand Drive, hal tersebut dikarnakan kurangnya mendapat koreksi kesalahan gerak dari dosen dan umpan balik dalam proses pembelajran. Ditinjau dari hasil belajar khususnya mata pelajaran Mata kuliah tenis meja materi tenis meja kebanyakan mahamahasiswa masih memiliki nilai di bawah nilai standar KKM (Ketuntasan Kriteria Minimum). Dimana nilai KKM (Ketuntasan Kriteria Minimum) yang ditetapkan di sekolah tersebut adalah 75. Dari 30 orang mahamahasiswa yang menjadi sampel dalam penelitian ini, ternyata hanya 4 orang mahamahasiswa $(13,33 \%)$ yang memiliki ketuntasan belajar, sedangkan selebihnya 26 orang mahamahasiswa $(86,67 \%)$ belum memiliki ketuntasan belajar. Nilai Persentase Peningkatan Hasil (PPH) ratarata kelas yang diperoleh hanya mencapai $46,30 \%$.

Dari Keterangan beberapa mahamahasiswa hasil wawancara bersama peneliti dapat disimpulkan bahwa, kegiatan pembelajaran mata kuliah tenis meja yang berlangsung, dosen masih menjadi pusat pembelajaran dan kurang melibatkan peran mahamahasiswa secara aktif, dengan kecenderungan mendengarkan dan mengaplikasikan apa yang disampaikan oleh dosen pengampu matakuliah, sehingga mengakibatkan proses pembelajaran yang berlangsung kurang di pahami oleh mahamahasiswa secara optimal. Model metode-metode praktek ditekankan pada teacher centered dimana para mahamahasiswa melakukan latihan praktek berdasarkan perintah yang ditentukan oleh dosen, latihan-latihan tersebut tidak dilakukan mahamahasiswa sesuai dengan inisiatif sendiri. Gaya ini akan berpengaruh terhadap kurangnya keaktifan mahamahasiswa dalam partisipasinya saat pembelajaran berlangsung.

Kurangnya partisipasi mahamahasiswa dalam mengikuti pembelajaran mata kuliah tenis meja akan berakibat menurunya tingkat keberhasilan mahamahasiswa dalam belajar. Oleh karena itu diperlukan suatu tindakan yang mampu melibatkan peran aktif mahamahasiswa dalam mengikuti pembelajaran mata kuliah tenis meja, dengan cara menggunakan iptek dalam proses belajr mengajar yang digunakan oleh dosen mata kuliah tenis meja dalam mengajar mahamahasiswa . Salah satunya adalah denganmenggunakan audio visual.

Banyak faktor yang mempengaruhi hasil belajar mahamahasiswa, diantaranya adalah motivasi, minat, bakat, semangat, kondisi fisik, sarana atau media pembelajaran, dosen, dan strategi pembelajaran yang digunakan oleh dosen dan lain-lain. Menyadari hal tersebut, perlu adanya suatu pembaharuan dalam pembelajaran utuk memungkinkan mahamahasiswa dapat mempelajari mata 
kuliah tenis meja kesehatan dan khususnya materi tenis meja menjadi lebih mudah, lebih cepat, lebih bermakna, efektif dan menyenangkan.

Untuk itu diperlukan suatu cara agar mahamahasiswa dapat menguasai gerakan dengan benar sehingga akan menghasilkan pukulan Forehand Drive yang maksimal. Jika selama ini dosen mata kuliah tenis meja kesehatan menyajikan materi pelajaran tenis meja lewat informasi contoh ( peragaan ) maka pada kesempatan kali ini dosen menyajikan informasi melalui media visual yang berupa gambar kepada mahamahasiswa. Dengan memanfaatkan media visual ini, diharapkan mahamahasiswa dapat memahami dan melakukan gerakan pukulan Forehand Drive dengan benar. Dalam media visual mahamahasiswa dapat menyaksikan atau melihat teknik dan bentuk cara melakukan gerak-gerak. Sehingga dengan digunakan media visual ini, membantu daya penalaran mahamahasiswa untuk dapat mengerti akan gerak dasar yang sebenarnya. Berdasarkan uraian diatas maka penulis tertarik untuk melakukan penelitian tentang penerapan penggunaan pembelajaran SAVI untuk meningkatkan hasil belajar pukulan Forehand Drive dalam permainan tenis meja pada mahamahasiswa jurusan PJKR Smester Ganjil FIK Unimed.

\section{Pustaka}

Tenis Meja merupakan permainan yang bersifat individual yang dapat dilakukan dengan cara satu orang melawan satu orang atau dua orang melawan dua orang. Permainan ini menggunakan Bet sebagai alat pemukul dan bola sebagai objek pukul, meja permainan berbentuk segi empat dan dibatasi oleh net untuk memisahkan antara daerah permainan sendiri dengan daerah permainan lawan. Tujuan permainan Tenis Meja merupakan berusaha untuk menjatuhkan bola di daerah permainan lawan secepat mungkin dan berusaha agar lawan tidak dapat mengembalikan bola kedaerah permainan kita lagi. Pada saat permainan berlangsung, masing-masing pemain harus berusaha agar bisa mengembalikan bola kembali kedaerah permainan lawan.Apabila bola jatuh ke daerah permainan lawan dan tidak bisa dikembalikan atau menyangkut ke net, maka permainan terhenti.

Negara asal tenis meja yang sebenarnya tidak diketahui. Olahraga ini dimulai kira-kira tahun 1890-an sebagai permainan pendatang dan menyebarkan keranjingan akan olahraga ini di seluruh kota dan tidak lama kemudian menghilang. Tenis meja menjadi populer kembali pada tahun 1920-an dan klubklub bermunculan di seluruh dunia. Nama aslinya, ping-pong, adalah dari nama merk dagang parker brothers, dari ping-pong diubah menjadi tenis meja. Federasi Tenis Meja Internasional (ITTF) didirikan pada tahun 1926.Asosiasi Tenis Meja Amerika Serikat (USTTA) didirikan pada tahun 1933. Sebagai permainan pendatang, olahraga ini sering dimainkan dengan bola yang terbuat dari gabus dan bet dari kulit binatang. Pada tahun 1920-an bet yang terbuat dari kayu berlapiskan getah karet mulai digunakan. Ini adalah bet getah karet yang pertama, dan jenis yang paling populer hingga tahun 1950 .

Pada saat itu terdapat dua tipe permainan yang dominan: hitter dan chopper. Hitter biasanya memukul apa saja sedangkan chopper akan mundur 10 
atau bahkan 20 kaki dari meja, dan mengembalikan bola dengan pukulan backspin. Karena serangan pemain dengan getah karet sangat terbatas, maka tipe chopper mendominasi. Hal ini menimbulkan masalah apabila dua pemain tipe chopper bermain bersamaan, keduanya akan memukul bola bolak-balik selama berjam-jam, menunggu lawannya untuk menyerang dan membuat kesalahan. Hal ini dihentikan dengan dibuatnya peraturan ekspedit. Peraturan ini membantu pemain menyelesaikan satu set tidak lebih dari 15 menit. Pada saat ekspedit disebutkan, pemain-pemain harus bergantian melakukan servis, dan siapa yang melakukan servis harus menang dalam 13 pukulan, termasuk servis. Wasit menghitung setiap pukulan dengan keras dan memberikan point pada penerima bola bila ia mengembalikan 13 pukulan secara berurutan. Ini membuat pemain yang melakukan servis memainkan rally yang panjang dan membosankan dengan agresif.

Pada tahun 1952, seorang pemain dari Jepang yang relatif tidak terkenal bernama Hiroje Satoh menunjukkan jenis bet yang aneh pada kejuaraan dunia. Betnya terbuat dari sebilah kayu yang dilapisi dengan selembar pons tebal. Dengan mudah ia memenangkan pertandingan tersebut, dan sejak saat itu terjadi perubahan alam dunia tenis meja. Selama 10 tahun berikutnya, hampir seluruh permainan top mengganti betnya. Ada dua tipe yang dikembangkan: interved dan pip-out. Tipe interved memungkinkan pemain untuk melakukan pukulan berputar yang lebih jauh dari yang biasanya, dan kedua tipe ini membuat serangan dan serangan balik lebih kudah dilakukan. Amerika, yang menguasai tenis meja hingga saat ini (urutan pertama pada kejuraan dunia tahun 1952 adalah Marty Reisman dari Amerika), lambat membuat perubahan, dan pada tahun 1960-an hampir menjadi juru kunci dari peringat dunia. Pada awal tahun 1960-an, pemainpemain mulai memnyempurnakan permainan dengan bet dari spons. Pertama mereka mengembangkan pukulan putar (pukulan topspin yang keras), dan tak lama kemudian pukulan ini menjadi tipe yang paling populer. Servis spin dikembangkan, seperti gerakan memotong, yang menjadi senjata utama Nobuhiko Hasegawa dari Jepang pada kejuaraan dunia tahun 1967.

Jepang mendominasi pertandingan selama tahun 1950-an, umumnya karena pemainnya menggunakan bet yang berlapis spons. Mereka juga memperkenalkan penhold grip (cara memegang bet seperti memegang pena), yang membuat mereka mendominasi pukulan forehand. Cina pada awalnya hanya menggunakan penhold grip (cara memegang bet seperti berjabatan tangan) yang mulai mendominasi pada awal tahun 1960-an mereka mendominasi pertandingan hampir berturut-turut hingga kejuaraan dunia tahun 1989 dimana Swedia menghilangkan masa-masa suram dengan mengalahkan cina 5-0 untuk kejuaraan beregu. Swedia mengulangi kemenangannya pada kejuaraan Dunia tahun 1991, kali ini mengalahkan Yugoslavia di final, dan Cina jatuh keperingkat 7, tapi kebanyakan hasil turnamen menunjukkan mereka bangkit untuk menjadi paling tidak yang kedua terbaik di dunia. Dalam olahraga tenis meja ada beberapa peralatan dan fasilitas yang perlu di persiapkan.

Untuk dapat bermain Tenis Meja dengan baik dan benar, seorang pemain harus menguasai teknik-teknik pukulan, pada dasarnya ada dua teknik memukul

PJKR_

http://jurnal.unimed.ac.id/2012/index.php/jpehr/index 
dalam Tenis Meja yaitu forehand dan backhand, Pukulan forehand adalah pukulan topspin yang agresif dianggap penting dengan tiga alasan pertama, anda memerlukan pukulan ini untuk menyerang, kedua, pukulan ini bisa menjadi pukulan utama untuk melakukan serangan, ketiga, pukulan ini yang paling sering dalam permainan dan lebih kuat dari pada backhand.Pukulan forehand memiliki keunggulan pada kerasnya laju bola sedangkan pukulan backhandakan mempermudah untuk menghadapi pukulan backspin dan topspin, kedua teknik memukul ini mendasari berbagai jenis pukulan. Pukulan forehand dilakukan jika bola berada disebelah kanan tubuh. Cara melakukan pukulan ini adalah dengan merendahkan posisi tubuh, lalu gerakkan tangan yang memegang bet kearah pinggang, siku membentuk sudut kira-kira $90^{\circ}$. Sekarang tinggal menggerakkan tangan kedepan tanpa merubah siku. Sedangkan pukulan backhand disebelah kiri badan. Cara melakukannya pertama rendahkan posisi tubuh lalu gerakkan tangan kearah pinggang sebelah kiri jika tidak kidal, dengan sudut siku $90^{\circ}$. Gerakkan tangan dan bet kearah depan, jaga siku agar tetap $90^{\circ}$ dan bet tetap lurus.

Dengan demikian dapat disimpulkan bahwa kedua teknik dasar memukul dengan cara Forehand dan Backhand merupakan suatu teknik dasar yang sangat penting yang harus dikuasai oleh setiap pemain. Sebagaimana telah kita ketahui bahwa Forehand dan Backhand lah yang merupakan tulang punggung dari permainan kita.

Adapun beberapa jenis stroke (pukulan) yang dikenal dalam olahraga Tenis meja, tidak kurang pula berbagai bentuk pukulan yang hampir serupa namun mempunyai nama yang berbeda. Menurut Kertamanah(2003:27), “jenisjenis pukulan dalam Tenis meja yaitu Drive, push, block, smash, hit, servis, servis return, loop, side slip shot, half-volley, drop shot, short cut, long cut, lobbin, flick". Salah satunya adalah pukulan forehanddrive yang baikmemungkinkan seorang pemain mampu menciptakan poin.Oleh karena itu gerakan forehanddrive memiliki peranan yang sangat penting dan tidak dapat dikesampingkan.

Dalam penelitian ini yang akan dibahas adalah keterampilan forehanddrive. Damari \& Kusmaedi (1991: 79) mengemukakan bahwa "Drive adalah teknik pukulan yang dilakukan dengan gerakan bet dari bawah sorong keatas dan sikap bet tertutup"Besarnya sudut yang diakibatkan oleh gerakan bet dari kemiringan bet bervariasi sesuai dengan arah jatuhnya bola, kecepatan datangnya bola, putaran bola yang dating dari lawan dan tujuan dri pukulan drive itu sendiri. Drive dapat digunakan sebagai pukulan serangan atau dapat juga kita control sesuai dengan keinginan.

Pukulan drive, yang sering juga disebut lift, merupakan dasar dari berbagai jenis pukulan serangan. Oleh karena itu, pukulan drive disebut pula sebagai induk teknik dari pukulan. Menurut Kertamanah (2003:27).ada beberapa sifat istimewa dari pukulan driveantaralain:

- Tinggi atau rendah terbang bola di atas ketinggian garis net mudah dikuasai.

- Cepat maupun lambatnya laju bola tidak akan susah dikendalikan.

- Bola drivetidak mengandung tenaga yang terlalu keras.

- Bola bersifat membawa sedikit perputaran. 
- Dapat dilancarkan disetiap posisi titik bola di atas meja tanpa merasakan kesulitan terhadap bola-bola berat, ringan, cepat, lambat, tinggi, maupun rendah, serta terhadap berbagai jenis putaran bola.

Drive merupakan salah satu teknik pukulan yang penting untuk Menghadapi permainan defensif, Damiri (2001) menambahkan bahwa beberapa hal yang harus diperhatika dalam melakukan teknik pukulan drive:

- Perhatikan arah jatuhnya bola dan segera mengambil posisi sesuai dengan arah jatuhnya bola.

- Ambil posisi sidestance, pandangan mata terus mengikuti lajunya bola.

- Dengan bergerak maju atau mundur kesamping bet menyentuh atau mengenai bola pada waktu berada pada ketinggiannya, pukulan diperkuat dengan perputaran tubuh dari tungkai dan kaki dan pinggang ke atas.

- Lanjutkan gerakan lengan setelah perkenaan pada bola sampai bet berada di samping kiri depan kepala untuk pukulan tangan kanan danm sebaliknya untuk pukulan tangan kiri.

- Kembali keposisi siap sedia menerina pengambilan bola berikutnya. Untuk dapat melakukan pukulan forehand drive dengan baik, harus dapat menguasai teknik pukulan forehand drive yang dikemukakan oleh Akhmad Jaya, dkk (2003) adalah:

Sikap permulaan:

- Sikap kaki kiri didepan, kaki kanan dibelakang.

- Badan agak menyerong ke kanan $45^{\circ}$.

- Lutut agak dibengkokkan. Sikap saat perkenaannya:

- Racket ditarik kesamping badan agak ke belakang.

- Kepala racket agak menghadap tanah dengan lengan agak ke bawah.

- Pergelangan tangan tidak boleh dibegkokkan.

- Kemudian lengan kita ayun ke depan kiri atas dengan menggesek di bagian belakangnya bola kosong dan dengan menggesek di bagian bawahnya bola untuk bola sisi.

Sikap Akhir:

- Supaya bola berjalan dengan suatu garis lengkung melewati net kearah lawan, pergelangan tangan ikut membantu menggesek bola ke atas, sehingga racket berhenti di samping kiri atas kepala.

- Pada waktu melakukan forehand drive tersebut pinggang membantu gerakan badan dari badan dari kanan ke kiri, sehingga keseimbangan badan dari kaki kanan pindah ke kaki kiri.

Cara pukulan drivemenurut Sutarmin (2007: 27) adalah:

- Bola yang datang dari arah lawan diterima dengan gerakan bet dipukulkan pada bola, posisi bet dalam dengan gerakan dari bawah ke atas, posisi bet dalam keadaan tertutup.

- Pukulan drive dapat dilakukan untuk menyerang lawan dan mengontrol bola.

- Pukulan drive dapat dilakukan secara Forehand dan backhand.

PJKR_

http://jurnal.unimed.ac.id/2012/index.php/jpehr/index 
SAVI singkatan dari Somatic, Auditori, Visual dan Intektual. Teori yang mendukung pembelajaran SAVI adalah Accelerated Learning, teori otak kanan/kiri; teori otak triune; pilihan modalitas (visual, auditorial dan kinestetik); teori kecerdasan ganda; pendidikan (holistic) menyeluruh; belajar berdasarkan pengelaman; belajar dengan symbol. Pembelajaran SAVI menganut aliran ilmu kognitif modern yang menyatakan belajar yang paling baik adalah melibatkan emosi, seluruh tubuh, semua indera, dan segenap kedalaman serta keluasan pribadi, menghormati gaya belajar individu lain dengan menyadari bahwa orang belajar dengan cara-cara yang berbeda. Mengkaitkan sesuatu dengan hakikat realitas yang nonlinear, nonmekanis, kreatif dan hidup.

Somatis berasal dari bahasa Yunani yang berarti tubuh - soma (seperti dalam Psikosomatis). Jadi belajar somatis berarti belajar dengan indera peraba, kinestetis, praktis, dalam arti melibatkan fisik dan menggunakan serta menggerakkan tubuh sewaktu belajar.

Lebih lanjut Meier mengemukakan bahwa " Somatis adalah belajar dengan bergerak dan berbuat". Sedangkan menurut Dennison (2002: 101) menyatakan bahwa " belajar somatis berarti belajar dengan indara peraba, melibatkan fisik dan menggunakan serta menggerakkan tubuh sewaktu belajar".

Lalu bagaimana pendekatan SAVI (Somatis, Auditori, Visual, Intelektual) digunakan dalam proses pencapaian hasil belajar? Pendekatan SAVI (Somatis, Auditori, Visual, Intelektual) digunakan dalam proses pencapaian hasil belajar adalah dengan cara mahamahasiswa dibebaskan menggerakkan tubuhnya sewaktu belajar, dosen sebagai fasilitator yang apabila mahamahasiswa terbentur dalam masalah maka dosen harus dapat memberi penjelasan dan memberikan pengertian secara utuh yang dapat dipahami oleh mahasiswa.

\section{Metode}

Metode yang digunakan dalam penelitian ini yaitu metode penelitian tindakan kelas (Classroom Action Research). Menurut Arikunto (2009: 3) "Penelitian tindakan kelas adalah suatu pencermatan terhadap kegiatan belajar berupa sebuah tindakan, yang sengaja dimunculkan dan terjadi dalam sebuah kelas secara bersama". Pendekatan yang digunakan adalah pendekatan Kuantitatif yang berguna untuk mengungkapkan kesulitan belajar mahamahasiswa dalam proses pembelajaran Penjas. Serta cara mengatasi kesulitan-kesulitan tersebut sebagai upaya untuk meningkatkan hasil belajar mahamahasiswa pada materi tersebut. Sesuai dengan jenis penelitian ini, yaitu penelitian tindakan kelas maka penelitian terdiri dari beberapa tahap yang berupa siklus.

\section{Pembahasan}

Pelaksanaan Siklus I

Hasil Observasi yang dilakukan memperhatikan kemampuan awal mahasiswa kurang memuaskan, terbukti dengan hasil tes pertama mahasiswa 
yang mencapai ketuntasan belajar hanya 4 orang $(13,33 \%)$ dan yang belum mencapai ketuntasan belajar 26 orang $(86,67 \%)$.

Pembelajaran disiklus I yang mahasiswa melakukan pemanasan dan peneliti memberikan tugas setiap mahasiswa melakukan sesuai dengan kemampuan masing-masing, dimana mahasiswa tersebut melakukan kegiatan tersebut sesuai dengan rancangan yang peneliti buat, setelah itu mahasiswa dites dengan 1 pasang mahasiswa dimana mahasiswa 1 melakukan pukulan forehand drive sebanyak 5 kali dan 1 lagi memantulkan bola.

Untuk mempermudah dalam melihat hasil belajar mahasiswa dari siklus I secara visual dapat dilihat pada gambar dibawah ini:

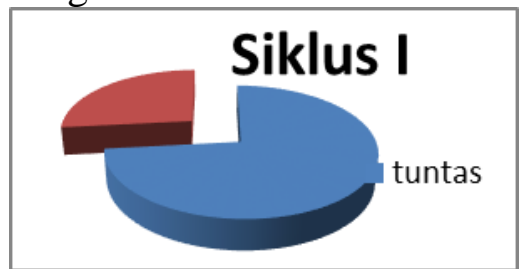

Gambar 1. Perbandingan Ketuntasan Belajar Pada Siklus I

Pengamatan selama berlangsungnya kegiatan belajar mengajar mengamati kemampuan mahasiswa mulai dari awal pelaksanaan tindakan sampai berakhirnya tindakan. Secara umum berdasarkan hasil observasi forehand drive tenis meja menunjukkan hasil $66,67 \%$ mahasiswa mengetahui gerakan dalam pukulan forehand drive. Hal ini menunjukkan bahwa mahasiswa mendengarkan penjelasan guru di dalam proses pembelajaran.

Dari data yang diperoleh terlihat bahwa kemampuan awal (pre-test) sebelum diberi pembelajaran menggunakan Penerapan media audio visual dalam melakukan forehand drive masih tergolong rendah, dari 30 mahasiswa terdapat 4 mahasiswa yang masih mendapat nilai tingkat ketuntasan belajar, sedangkan 26 mahasiswa belum mencapai tingkat ketuntasan belajar. Untuk melihat hasil belajar sebelum menggunakan Penerapan media audio visual dalam bentuk tabel selengkapnya dapat dilihat pada lampiran 3, selanjutnya dilakukan pemberian Penerapan media audio visual pada proses belajar, dari 30 mahasiswa terdapat 20 mahasiswa $(66,67 \%)$ yang telah mendapat nilai ketuntasan dalam belajar sedangkan 10 mahasiswa $(33,33 \%)$ belum mencapai tingkat ketuntasan belajar.

\section{Pelaksanaan Siklus II}

Hasil Test pada siklus II yang dilakukan memperlihatkan kemampuan mahasiswa meningkat jika dibandingkan dengan tes awal pada siklus I yaitu 28 orang mahasiswa $(93,33 \%)$ yang mencapai ketuntasan belajar dan yang belum mencapai ketuntasan belajar sebanyak 2 orang $(6,67 \%)$.

Untuk mempermudah dalam melihat hasil belajar mahasiswa dari siklus II secara visual dapat dilihat pada gambar di bawah ini:

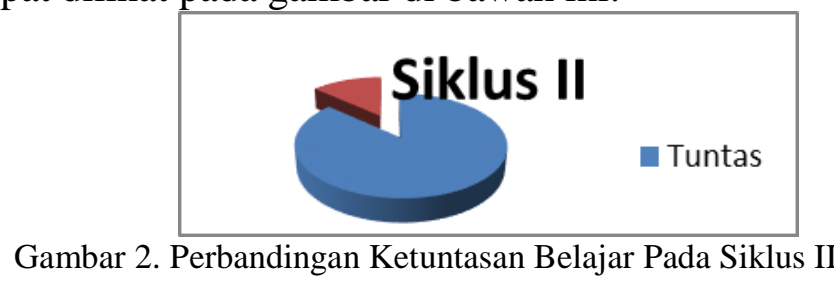

PJKR_

http://jurnal.unimed.ac.id/2012/index.php/jpehr/index 
Dalam siklus II ini proses belajar mengajar berjalan lebih baik jika dibandingkan dengan siklus I. Jika pada siklus I aktivitas mahasiswa secara keseluruhan hanya 64,45\% kemudian meningkat pada siklus II menjadi 85,96\%.

Dari data hasil belajar siklus II yang di dapat terlihat bahwa kemampuan mahasiswa dalam melakukan tes hasil belajar secara klasikal sudah meningkat. Dari 30 mahasiswa terdapat 28 mahasiswa (93,33\%) yang telah mencapai ketuntasan belajar, sedangkan 2 mahasiswa $(6,67 \%)$ yang belum mencapai ketuntasan belajar. Dalam siklus II ini proses belajar mengajar berjalan lebih baik jika dibandingkan dengan siklus I. Jika pada siklus I aktivitas mahasiswa secara keseluruhan hanya 66,67\% kemudian meningkat pada siklus II menjadi 93,33\%.

Dapat disimpulkan bahwa pembelajaran forehand drive tenis meja melalui Penerapan media audio visual yang tertuang pada hasil belajar I dan II mengalami peningkatan hasil belajar dan peningkatan ketuntasan belajar baik secara individual maupun klasikal.

Dari analisis data yang telah dilakukan dapat disimpulkan bahwa melalui Penerapan media audio visual, mahasiswa dapat meningkatkan hasil belajarnya pada pokok pembahasan forehand drive tenis meja. Dari analisis data juga dapat diketahui bahwa hasil belajar mahasiswa dari tes hasil belajar sebelum menggunakan Penerapan media audio visual masih sangat rendah. Maka dilakukan pemberian Penerapan media audio visual pada proses pembelajaran mahasiswa. Sehingga dapat diketahui bahwa hasil belajar mahasiswa dari tes hasil belajar siklus I menggunakan Penerapan media audio visual juga masih rendah, Hal ini di karenakan terdapat kesulitan-kesulitan yang di alami mahasiswa selama pembelajaran, antara lain sebagai berikut:

- Mahasiswa kurang mengerti saat melakukan forehand drive, yaitu pada saat sikap perkenaan.

- Mahasiswa kurang mampu melakukan Forehand Drive dengan posisi badan sebenarnya

- Mahasiswa terlalu fokus melihat net sehingga unsur geraknya terabaikan. Untuk mengatasinya guru menjelaskan tujuan pembelajaran dan memberikan motivasi kepada mahasiswa.

Dari hasil penelitian yang dilakukan, terlihat bahwa pada siklus I sebesar 66,67\%, kemudian meningkat pada siklus II menjadi 93,33\%. Hasil belajar forehand drive tenis meja dari mahasiswa secara keseluruhan masih mencapai $66,67 \%$. Kemudian sosuli rancangan yang diberikan pada pembelajaran siklus II antara lain :

- Sebelum pembelajaran di mulai mahasiswa di pertotonkan vidio tes siklus I meraka sendiri sehingga dapat di evaluasi kesalahan-kesalahan pada siklus I.

- Dilakukan pengelompokan-pengelompokan mahasiswa yang sudah tuntas dan yang belum tuntas sehingga dapat dijadikan patner dalam pembelajaran.

- Memvariasikan pembelajaran dengan gerakan-gerakan termudah bagi mahasiswa. 
- Memberikan bimbingan khusus terhadap mahasiswa -mahasiswa yang belum tuntas secara KKM.

Kemudian pada siklus II berdasarkan hasil refleksi ternyata membawa peningkatan menjadi $85,56 \%$. Namun, apabila dilihat dari aspek penilaian yaitu gerak lanjutan masih lebih rendah dari aspek yang lainnya. Pembelajaran forehand drive tuntas setelah siklus II, ini dikarenakan pemberian motivasi yang memicu semangat mahasiswa untuk belajar. Sedangkan pada siklus I, mahasiswa belum terbiasa dengan metode pengajaran yang diberikan guru, sehingga mahasiswa perlu beradaptasi dengan metode belajar yang diberikan oleh guru. Salah satu penyebab ketidak berhasilan pencapaian tujuan program pengajaran yang direncanakan adalah kekurangan pengetahuan atau ketidakmampuan untuk membuat variasi mengajar yang lain sehingga anak didik tidak dapat mencapai tujuan pengajar.

Kendala yang dihadapi mahasiswa dalam proses belajar mengajar karena kurang terbiasa dengan metode pengajaran yang diberikan guru. Karena selama ini metode mengajar yang diterima mahasiswa tidak pernah bervariasi dan menggunakan audio visual. Hal ini sejalan dengan pendapat Soeitoe (1990: 52) "Salah satu penyebab ketidakberhasilan pencapaian tujuan program pengajaran yang direncanakan adalah kekurangan pengetahuan atau ketidakmampuan untuk memilih gaya mengajar yang digunakan sehingga anak didik tidak dapat mencapai tujuan pengajar".

Oleh karena itu diharapkan peran serta lembaga pendidikan dan keguruan dalam menyiapkan tenaga-tenaga pendidik terutama guru yang akan memberikan pengajaran di dalam dan diluar kelas. Dalam artian pengajar harus mampu memilih dan menerapkan metode pembelajaran yang di prediksi akan lebih efektif untuk memudahkan mahasiswa dalam belajar di kelas dan diluar kelas maupun belajar mandiri. Suksesnya seseorang dalam pelajarannya adalah sebagai hasil kesanggupan dan kemampuan yang ada pada mahasiswa, sebagian lagi karena metode mengajar dan belajar yang tepat dan sebagian lagi karena lingkungan.

Banyak bentuk yang bisa digunakan dalam pembelajaran termasuk pembelajaran penjas di sekolah, misalnya Penerapan media audio visual. Dalam bentuk Penerapan media audio visual akan melibatkan mahasiswa di dalam suatu proses penemuan tertentu dengan melihat pengalaman pengamatan vidio. Mengembangkan hubungan yang tepat antara respon mahasiswa dengan yang diberikan guru. Memberikan bentuk pembelajaran yang bervariasi untuk menemukan kemampuan-kemampuan mahasiswa dalam bermain tenis meja, dan memupuk kesabaran antara guru dan mahasiswa yang diperlukan dalam proses pembelajaran. Variasi ini membutuhkan sedikit keterampilan kognitif. Penerapan media audio visual merupakan bentuk yang pertama-tama mahasiswa di dalam penemuan. Inti sari dari ini adalah sebuah fakta hubungan guru dan mahasiswa yang sesuai dengan bentuk Variasi guru menimbulkan respon tunggal yang ditemukan oleh mahasiswa. Pengaruh komulatif dari rangkaian ini adalah sebuah proses yang memandu mahasiswa untuk menemukan konsep yang dicari, prinsip atau gagasan yang dapat meningkatkan hasil belajar mahasiswa khususnya hasil belajar pukulan forehand drive.

PJKR_

http://jurnal.unimed.ac.id/2012/index.php/jpehr/index 


\section{Simpulan}

Setelah dibahas pada BAB IV dapat ditarik kesimpulan bahwa pembelajaran melalui penerapan media audio visual dapat meningkatkan hasil belajar pukulan forehand drive tenis meja pada mahasiswa PJKR FIK-Unimed.

\section{Rujukan}

Arikunto, 2009. Prosedur penelitian Suatu Pendekatan Praktik. Jakarta: Rineka Cipta.

Achmad dan Nurlan Kusmaedi, 1991. Olahraga pilihan Tenis Meja. Bandung: Departemen Pendidikan dan Kebudayaan direktorat Jendral pendidikan tinggi.

Akhmad Jaya dkk, 1976. Teknik Permainan Tenis Meja. Bandung: PTMSI.

Djamarah, dan Aswan Zain, 2002. Strategi belajar mengajar. Jakarta: Rineka Cipta.

Hamalik, Oemar, 1985. Psikologi belajar dan mengajar. Bandung: Sinar baru Algensindo.

Larry Hodges, 2007. Tenis Meja. Jakarta: Raja Grafindo Persada.

Muhajir, 2007. Pendidikan Jasmani. Jakarta: Penerbit Yudhistira.

Mulyono, 2009. Pendidikan Bagi Anak Berkesulitan Belajar. Jakarta: Rineka Cipta.

Nurkencana, 1986. Evaluasi Pendidikan. Jakarta: Usaha Nasional.

Sadiaman Arief dkk, 2006. Media pendidikan, pengertian, pengembangan dan pemanfaatanya. Jakarta: Penerbit PT. Raja Grafindo Persada.

Slameto, 2010. Belajar dan Faktor-faktr yang Mempengaruhi. Jakarta: Rineka Cipta.

Suryosubroto B, 1997. Proses belajar mengajar di sekolah. Jakarta: Rineka Cipta. Sutarmin, 2007. Terampil Berolahraga Tenis Meja, Surakarta: Era Intermedia.

Kertamanah, 2003. Teknik \& Taktik Mahir Permainan Tenis Meja. Jakarta: Raja Grafindo Persada.

PJKR_

http://jurnal.unimed.ac.id/2012/index.php/jpehr/index 